\title{
Effect of different growth promoters on broiler performance and gut morphology
}

\author{
Efecto de diferentes promotores de crecimiento en el desarrollo y \\ morfología intestinal de pollos broiler \\ R Markovića*, D Šefer ${ }^{\mathrm{a}}$, M Krstićc ${ }^{\mathrm{b}}$, B Petrujkića \\ aDepartamento de Nutrición and ${ }^{\text {b}}$ Department of Chemistry, Faculty of Veterinary Medicine, \\ University of Belgrade, Belgrade, Serbia
}

\begin{abstract}
RESUMEN
Un total de 240 pollos broiler Hybro de 1 día de edad se dividieron en cuatro grupos. Estos grupos fueron alimentados con una dieta completa basada en maíz/soya, con y sin la adición de antibiótico promotor del crecimiento (AGP, Flavomycin ${ }^{\circledR}, 15$ PPM, Intervet), alimento microbiano dirigido (DFM, All-Lac ${ }^{\circledR} 0,1 \%$, Alltech Inc. USA) y Manano Oligosacárido (MOS) (Bio-MOS ${ }^{\circledR} 2$ kg/T, Alltech Inc. USA). Los pollos fueron introducidos en el experimento después de nacer. En el día 42 de ensayo todas las aves fueron sacrificadas en una planta de faenamiento y sus rendimientos al sacrificio fueron medidos. Muestras de intestinos con su contenido de 6 aves promedio, seleccionadas al azar de cada grupo $(\mathrm{n}=24)$, fueron tomadas para su examen. Al final del ensayo, el peso corporal (BW) y la ganancia diaria promedio (ADG) de los pollos alimentados con las raciones que contenían Bio-MOS $^{\circledR}(1915,23$ y 44,58 g), AGP $(1869,40$ y 43,50 g) y DFM (1855,50 y 43,17 g) fueron significativamente mayores que las de los pollos del grupo control (1815,67 y 41,96 g). Comparado con el grupo control (91,19 g), el consumo promedio diario de alimento (ADFI) también fue reducido significativamente en los grupos experimentales suplementados con Bio-MOS ${ }^{\circledR}(81,84 \mathrm{~g})$, DFM $(83,50 \mathrm{~g})$ o AGP $(86,16$ que g), lo cual disminuyó la relación de conversión (FCR) de 2,17 en el grupo control a 1,83, 1,93 y 1,98 kg, respectivamente. Una disminución significativa del pH del contenido intestinal en diversas partes del tracto gastrointestinal fue observada en los grupos de pollos suplementados con Bio-MOS $(6,25,6,50$ y 6,78) y DFM $(6,16,6,46$ y 6,72), comparado con los grupos control $\left(6,55,6,81\right.$ y 7,21) y adicionado de AGP $\left(6,61,6,87\right.$ y 7,14). El uso de DFM y de Bio-MOS ${ }^{\circledR}$ aumentó la longitud y el ancho de las vellosidades intestinales y disminuyó la profundidad de criptas. El número de células caliciformes no se diferenció estadísticamente entre grupos experimentales. En conclusión, los grupos suplementados con Bio-MOS ${ }^{\circledR}$ y DFM presentaron ventajas nutricionales, farmacológicas y económicas con respecto al grupo que incorporó un promotor de crecimiento antibiótico.
\end{abstract}

Key words: broiler, additives, performance, gut morphology.

Palabras clave: pollo broiler, promotor de crecimiento, rendimiento, morfología del intestino.

\section{INTRODUCTION}

The practice of feeding livestock with subtherapeutic levels of antibiotics has been in use for over fifty years. Antibiotics affect microflora by altering the metabolism of microorganisms, and suppresing microbial growth in the gut (Gadd 1997). Usage of antibiotics has negative effects on animal's health and production such as residua in tissues, long withdrawal period, and development of resistance in microorganisms, allergies and genotoxicity (Markovic 2005). In this trial 8\% Flavomycin ${ }^{\circledR}$, an antibiotic produced from culture of Streptomyces bambergiensis, was used.

Over the past few years, a great deal of interest has been generated on the evaluation of alternative means for manipulation of gastrointestinal microflora in livestock. The motivation for examining these alternatives comes from increased public scrutiny about the use of antibiotics in the animal feed industry as well as the need for a safe food supply. According to European legislation, all antibiotic growth promoters (AGP) are forbidden in feed. During

Accepted: 21.01.2009.

* radmilam@vet.bg.ac.rs the past few years numerous trials have been conducted to compare the incorporation of mannan-oligosaccharides (MOS) and direct feed microbials (DFM) in the diets, versus conventional AGP. Supplementation of poultry diets with commercially available MOS and DFM enhances profitability by improving performance parameters in live birds (Iji and Tivey 1998). Probiotics are additives composed of living microorganisms which induce beneficial effects in animal organism by eubiosis without antibiotic addition into the feed, as defined by Parker (1974), Fuller (1977) and Vanbelle et al (1990). Recently, DFM, a source of live microorganisms like bacteria, fungi and/or yeasts have been introduced (Miles and Bootwalla 1991). There are numerous mechanisms by which intestinal microflora inhibits gut colonisation with invasive microorganisms, as described by Rolfe (1991). These mechanisms include aggregation of lactic bacteria to pathogenic bacteria, competition at adherence site, nutritive competition between microorganisms and bactericide effects. The additives such as DFM contain some beneficial bacteria that coat the intestinal villa and prevent Coliform bacteria and other bacteria from attaching to the intestinal wall (Spring 1996). The active principles of All-LAC ${ }^{\circledR}$ are Lactobacillus acidophillus and Streptococcus faecium (minimum bacterial count $1,5 \times 10^{9} \mathrm{CFU} /$ colony forming units). 
Prebiotics have been defined as non digestible feed ingredients, which are growth substrates, specifically directed towards potentially beneficial bacteria already existing in caecum and colon. Several studies have shown that addition of prebiotics to the diet of broiler, layer and pig leads to improved performance through improving gut microflora (Xu et al 2003, Spring et al 2000, Pelicano et al 2004). In contrast to the antibiotic mode of action, which limits or suppresses growth of common Gram-positive microflora, mannan-oligosaccharides (Bio-MOS ${ }^{\circledR}$ ) and other oligosaccharides can prevent attachment of Gramnegative pathogens to enterocytes. Bio-MOS ${ }^{\circledR}$ derived from Saccharomyces cerevisiae cell wall, is commonly available as a feed supplement, and is included in diets as a generally recognised safe compound. The benefits of MOS are based on different specific properties including reduction of the intestinal mucous cells turnover rate (Iji and Tivey 1998). These properties have the potential to enhance growth rate and feed conversion in commercial broilers diet. Bacterial pathogens, which bind to the intestinal wall via mannose bearing lectins, bind to the dietary MOS instead and are eliminated harmlessly (Sharon and Lis 1993). The removal of AGPs has led to the search of alternative growth promoters. The alternative products must be safe for animals, consumers and the environment.

The objective of this trial was to investigate the effect of dietary supplementation with Bio-MOS ${ }^{\circledR}$ (Alltech Inc, USA), direct-fed microbials (All-Lac ${ }^{\circledR}$, Alltech Inc, USA) and antibiotic growth promoters (AGP, Flavomycin ${ }^{\circledR}$, Intervet) on the performances and gut morphology of broilers. The gastrointestinal tract is a front - defense line against the constant invasion of microbes. The gastrointestinal fauna of the bird is an important factor in poultry performance and flock health.

\section{MATERIAL AND METHODS}

The completely randomised experimental design included 240 one-day-old male broiler chicks (sexed, Hybro) from a commercial hatchery. Animals were fed commercial complete corn-soybean based diets (table 1). Diet 1 was used from $1^{\text {st }}$ to $20^{\text {th }}$ day, diet 2 from $21^{\text {st }}$ to $34^{\text {th }}$ day and finally diet 3 was used from $35^{\text {th }}$ until $42^{\text {nd }}$ day. Four treatment groups of 60 chickens each, were fed the diet with supplementation of AGP (15 ppm Flavomycin ${ }^{\circledR}$, AGP group), DFM (All-LAC ${ }^{\circledR} 1 \mathrm{~kg} / \mathrm{T}$, DFM group), $2 \mathrm{~kg} / \mathrm{T}$ Bio-MOS ${ }^{\circledR}$ (MOS group) and withouth additives (control group). All birds had ad libitum access to feed.

The following parameters were evaluated during the experimental period: body weight (on day 42), average body weight gain, feed intake and feed gain ratio. Feed intake was measured on a daily basis, as the difference between the feed mass given to the animals and the feed mass left in the rack. At day 42 of trial, all broilers were conventionaly sacrificed by cervical dislocation technique, as described in the Report of the AVMA Panel on Euthanasia (AVMA 2001).
Table 1. Composition of experimental diets at days 1- 42 of age. Composición de dietas experimentales entre 1- 42 días de edad.

\begin{tabular}{|c|c|c|c|}
\hline & \multicolumn{3}{|c|}{ Diet } \\
\hline & $\begin{array}{c}1 \\
\text { (1.-20. días) }\end{array}$ & $\begin{array}{c}2 \\
\text { (21.-34. días) }\end{array}$ & $\begin{array}{c}3 \\
\text { 35.-42. día) }\end{array}$ \\
\hline \multicolumn{4}{|l|}{ Ingredient } \\
\hline Maize & 56.73 & 63.30 & 67.75 \\
\hline Soybean meal & 26.30 & 15.30 & 17.00 \\
\hline Fishmeal & 4.00 & 4.00 & - \\
\hline Sunflower meal & - & 5.00 & 6.00 \\
\hline Gluten meal, corn & 6.00 & 6.00 & 4.00 \\
\hline Oil & 3.00 & 3.00 & 2.00 \\
\hline Limestone & 1.10 & 0.70 & 1.00 \\
\hline Dicalcium phosphate & 1.30 & 1.30 & 1.00 \\
\hline Salt & 0.20 & 0.25 & 0.25 \\
\hline Methionine & 0.12 & - & - \\
\hline Lysine & 0.25 & 0.15 & - \\
\hline $\begin{array}{l}\text { Vitamin-mineral } \\
\text { premix* }\end{array}$ & 1.00 & 1.00 & 1.00 \\
\hline \multicolumn{4}{|c|}{ Calculated composition \% } \\
\hline Protein & 21.80 & 19.40 & 17.30 \\
\hline $\mathrm{Ca}$ & 1.07 & 0.89 & 0.75 \\
\hline $\mathrm{P}$ & 0.74 & 0.75 & 0.61 \\
\hline $\mathrm{ME}, \mathrm{MJ} / \mathrm{kg}$ & 12.96 & 13.27 & 13.15 \\
\hline Lysine & 1.38 & 1.05 & 0.76 \\
\hline $\begin{array}{l}\text { Methionine + } \\
\text { cystine }\end{array}$ & 0.78 & 0.63 & 0.55 \\
\hline
\end{tabular}

* including Flavomycin ${ }^{\circledR}$, DFM or Bio-MOS ${ }^{\circledR}$.

Samples of small intestine (second third), which correspond to the surpass of duodenum to jejunum, and jejunum to ileum, were taken for examination from 6 average broilers (randomly selected) from each group $(n=24)$ Sections of 5-8 $\mathrm{mm}$ thickness were taken from each sample and fixed in $10 \%$ formalin solution and absolute alcohol and embedded in paraffin. Sections were cut, mounted on slides and stained with the HE method as described by Scheuer and Chalk (1986). Morphometric examinations (villus height and width, as well as crypt depth) were done by light microscopy using an ocular micrometer 1:100 as described by Djolai et al (1998), while stereologic determination of goblet cells number was carried out using a multipurpose test system M42 as described by Wiebel (1979). At the end of the trial, the $\mathrm{pH}$ of intestinal content in different gastrointestinal parts (duodenum, ileum, caecum) was measured.

\section{STATISTICAL ANALYSIS}

The values obtained were expressed as mean $\pm \mathrm{SD}$. In order to analise the relation between intergroup mean 
differences, ANOVA, Tukey and student's t-tests were performed at significance levels of $1 \%$ and 5\% (Snedecor and Cochran 1971). Software package PrismaPad v.4.0 was used for statistical calculation.

\section{RESULTS AND DISCUSSION}

Body weight, average growth, daily feed intake and feed gain ratio during the entire trial period are presented in table 2.

After 42 days, it was observed that the BW of the animals fed with Bio-MOS ${ }^{\circledR}$ diet differed significantly compared to the other groups $(\mathrm{P}<0.05)$. This led to significantly higher body weight gain in the experimental rather than in the control group during the total period $(\mathrm{P}<0.05)$. Feed conversion was also reduced significantly when BioMOS $^{\circledR}$, DFM or AGP were administered to the feed and this was observed during the entire trial period (table 2, $\mathrm{P}<0.05$ ). As a result, feed to gain ratio was significantly reduced in trial groups compared to the control and the AGP fed birds $(\mathrm{P}<0.05)$.
The data presented in the table 3 shows that electrochemical reaction increases along the digestive tract of broilers, with the highest values being registered in the terminal parts of the intestines in all groups included in the trial. The differences of $\mathrm{pH}$ values between control and AGP group among corresponding segments of the intestines were non-significant, while the decrease of the $\mathrm{pH}$ in the duodenal content ranged from significant $(P<0.05)$ to very significant $(P<0.01)$ in the other two groups.

The supplementation with Bio-MOS ${ }^{\circledR}$ and DFM led to an increase in villus height and width, as well as a decrease in crypt depth in all parts of the intestine $(\mathrm{P}<0.05)$, (table 4, figures 1-3).

Supplementation of animal diets with various additives aims to increase production and quality of food of animal origin. The results obtained in the present study are similar to those described by Roch (1998) and Waldroup et al (1970) obtained in nutrition experiments with antibiotic and Bio-MOS ${ }^{\circledR}$. Probiotics induce similar and even better effects compared to

Table 2. Average body weight (BW), average body broiler weight gain (BWG), average daily feed intake (ADFI) and average feed conversion ratio (FCR) during the entire trial period for the broiler treatment groups.

Promedios de peso corporal (BW), de aumento del peso corporal (BWG), del consumo diario de alimento (ADFI) y del cociente de conversión de la alimentación (FCR) durante el período de prueba completo para los grupos de broiler en tratamiento.

\begin{tabular}{lcccc}
\hline \multirow{2}{*}{ Parameters } & \multicolumn{2}{c}{ Group } & & \\
\cline { 2 - 5 } & Control & AGP* & DFM** & MOS*** \\
\hline BW (kg) & $1815.67^{\mathrm{a}}$ & $1869.40^{\mathrm{b}}$ & $1855.50^{\mathrm{c}}$ & $1915.23^{\mathrm{a}, \mathrm{b}, \mathrm{c}}$ \\
BWG (g/d) & $41.96^{\mathrm{a}, \mathrm{b}, \mathrm{c}}$ & $43.50^{\mathrm{a}}$ & $43.17^{\mathrm{b}}$ & $44.58^{\mathrm{c}}$ \\
ADFI (g/d) & 91.19 & 86.16 & 83.50 & 81.84 \\
FCR (kg) & 2.17 & 1.98 & 1.93 & 1.84 \\
\hline Values expressed as $\overline{\mathrm{x}} ;$ & & $\mathrm{a}, \mathrm{b}, \mathrm{c}$ P $<0.05$ & & \\
\hline
\end{tabular}

* AGP - Antibiotic Growth Promoters

** DFM - Direct Feed Microbials

*** MOS - Manan Oligo Saccharids

Table 3. Mean and standard deviation for $\mathrm{pH}$ value of chime in the intestine of broilers on day 42 .

Media y desviación estándar para el valor de $\mathrm{pH}$ del quimo en el intestino de los broilers en el día 42.

\begin{tabular}{|c|c|c|c|c|}
\hline \multirow{2}{*}{ Segment } & \multicolumn{4}{|c|}{ Group } \\
\hline & Control & AGP* & $\mathrm{DFM}^{* *}$ & $\operatorname{MOS} * * *$ \\
\hline Duodenum & $6.55 \pm 0.25^{\mathrm{a}, \mathrm{A}}$ & $6.61 \pm 0.26^{\mathrm{b}, \mathrm{B}}$ & $6.16 \pm 0.15^{\mathrm{A}, \mathrm{B}}$ & $6.25 \pm 0.21^{\mathrm{a}, \mathrm{b}}$, \\
\hline Ileum & $6.81 \pm 0.20^{\mathrm{a}, \mathrm{b}}$ & $6.87 \pm 0.33^{c, d}$ & $6.46 \pm 0.21^{\mathrm{c}}$ & $6.50 \pm 0.26^{b, d}$ \\
\hline Caecum & $7.21 \pm 0.33^{\mathrm{a}, \mathrm{b}, \mathrm{A}}$ & $7.14 \pm 0.24^{\mathrm{c}, \mathrm{d}}$ & $6.72 \pm 0.26^{\mathrm{b}, \mathrm{c}, \mathrm{A}}$ & $6.78 \pm 0.29^{a, d}$ \\
\hline Values expressed as $\bar{x} ; \mathrm{SD}$; & \multicolumn{2}{|c|}{$\mathrm{a}, \mathrm{b}, \mathrm{c}, \mathrm{d} \mathrm{P}<0.05$} & \multicolumn{2}{|c|}{$\mathrm{A}, \mathrm{B} \mathrm{P}<0.01$} \\
\hline
\end{tabular}

* AGP - Antibiotic Growth Promoters

** DFM - Direct Feed Microbials

*** MOS - Manan Oligo Saccharids 
Table 4. Effect of treatments on broiler gut morphology $[\mu \mathrm{m}]$ on day 42 .

Efecto de los tratamientos en la morfología del intestino de los broilers [ $\mu \mathrm{m}]$ en el día 42.

\begin{tabular}{|c|c|c|c|c|}
\hline & \multicolumn{4}{|c|}{ Group } \\
\hline & Control & AGP* & DFM** & $\operatorname{MOS} * * *$ \\
\hline \multicolumn{5}{|l|}{ Duodenum } \\
\hline Villus height & $901.28 \pm 70.02^{\mathrm{a}, \mathrm{b}}$ & $981.07 \pm 77.01^{\mathrm{c}, \mathrm{d}}$ & $1008.35 \pm 40.64^{\mathrm{a}, \mathrm{c}}$ & $1013.08 \pm 81.98^{\mathrm{b}, \mathrm{d}}$ \\
\hline Villus width & $93.72 \pm 15.11^{\mathrm{a}, \mathrm{b}, \mathrm{c}}$ & $98.58 \pm 8.10^{\mathrm{a}}$ & $104.48 \pm 17.40^{\mathrm{b}}$ & $107.70 \pm 13.91^{\mathrm{c}}$ \\
\hline Crypt depth & $140.35 \pm 27.20^{\mathrm{a}, \mathrm{b}}$ & $137.52 \pm 18.23^{c, d}$ & $126.18 \pm 30.06^{\mathrm{a}, \mathrm{c}}$ & $123.72 \pm 32.10^{\mathrm{b}, \mathrm{d}}$ \\
\hline \multicolumn{5}{|l|}{ Ileum } \\
\hline Villus height & $452.77 \pm 181.13^{\mathrm{a}, \mathrm{b}, \mathrm{A}}$ & $478.32 \pm 124.35^{\mathrm{c}, \mathrm{d}, \mathrm{B}}$ & $541.27 \pm 100.82^{\mathrm{a}, \mathrm{c}}$ & $640.53 \pm 115.95^{b, d, A, B}$ \\
\hline Villus width & $87.15 \pm 10.92^{\mathrm{a}}$ & $90.28 \pm 18.83^{\mathrm{b}}$ & $90.05 \pm 13.53^{c}$ & $95.12 \pm 12.30^{\mathrm{a}, \mathrm{b}, \mathrm{c}}$ \\
\hline Crypt depth & $111.93 \pm 14.06^{\mathrm{a}, \mathrm{b}}$ & $103.98 \pm 34.03^{c, d}$ & $84.20 \pm 24.90^{\mathrm{a}, \mathrm{c}}$ & $86.52 \pm 10.90^{\mathrm{b}, \mathrm{d}}$ \\
\hline \multicolumn{5}{|l|}{ Caecum } \\
\hline Villus height & $160.22 \pm 29.77^{\mathrm{a}, \mathrm{b}}$ & $163.08 \pm 48.67^{c}$ & $166.48 \pm 46.19^{a}$ & $171.25 \pm 44.06^{\mathrm{b}, \mathrm{c}}$ \\
\hline Villus width & $59.08 \pm 6.55^{\mathrm{a}, \mathrm{b}, \mathrm{c}}$ & $66.77 \pm 12.34^{\mathrm{a}}$ & $65.27 \pm 10.49^{b}$ & $65.10 \pm 16.29^{c}$ \\
\hline Crypt depth & $42.23 \pm 11.77^{\mathrm{a}, \mathrm{b}}$ & $40.83 \pm 8.67^{c, d}$ & $31.37 \pm 8.53^{\text {a. c }}$ & $31.75 \pm 7.82^{\text {b. d }}$ \\
\hline
\end{tabular}

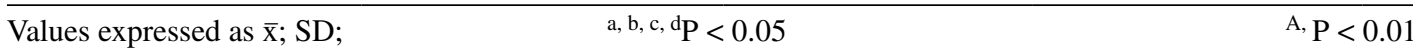

* AGP - Antibiotic Growth Promoters.

** DFM - Direct Feed Microbials.

*** MOS - Manan Oligo Saccharids.

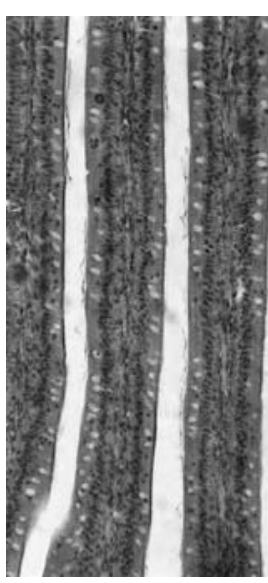

a. Control
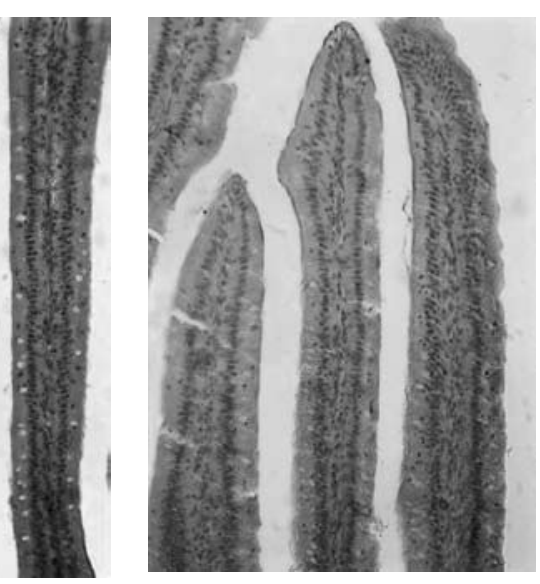

b. AGP

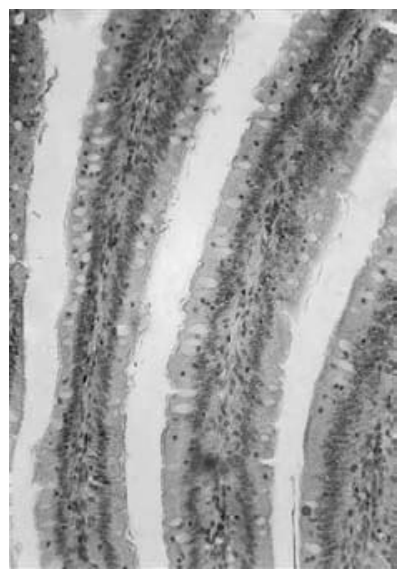

c. DFM

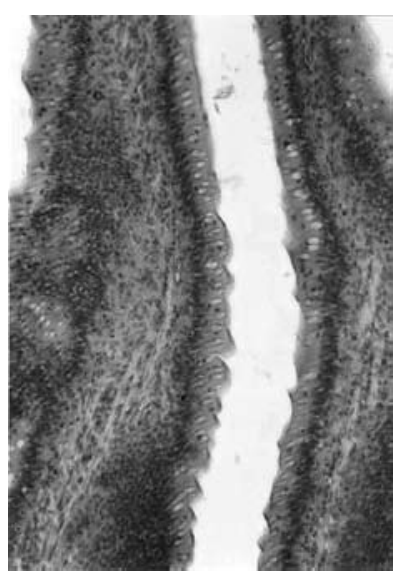

d. MOS

Figure 1. Histological figure of broiler duodenum (obj. 1:100, HE) for different treatment groups.

Figura histológica de duodeno de broiler (obj. 1:100, HE) para los diversos grupos en tratamiento.

Flavomycin ${ }^{\circledR}$ as defined by Owings et al (1990). The increased weight gain is achieved by prebiotics and the increased range from 2-6\%, as reported by Kumprecht et al (1998), Roch (1998), Petersen (1998), Newman Melissa (1990) and Pupavac et al (1998). This was also confirmed in our trial for prebiotic supplementation (MOS group).
Adding MOS in broiler feed significantly increased villous length but not villous width as reported by Spring (1996). Besides Bradly et al (1994) noticed simultaneous decrease of crypt depth, which is in agreement with reports by Savage et al (1997).

There is substantial evidence that dietary MOS modifies the morphology and structure of the intestinal mucous as 


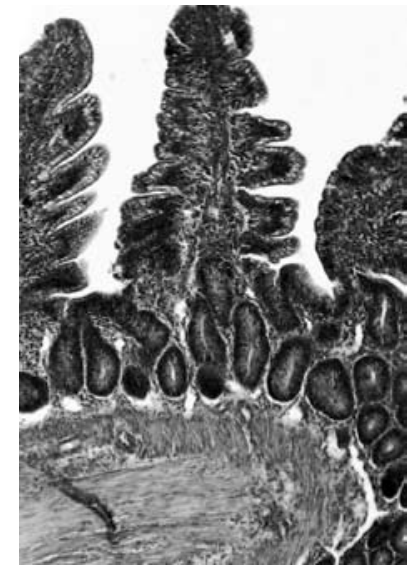

a. Control

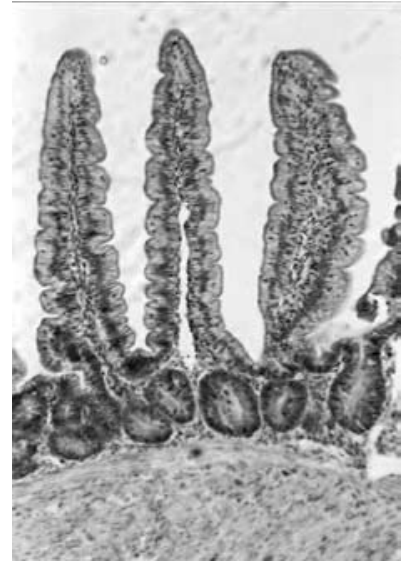

b. AGP

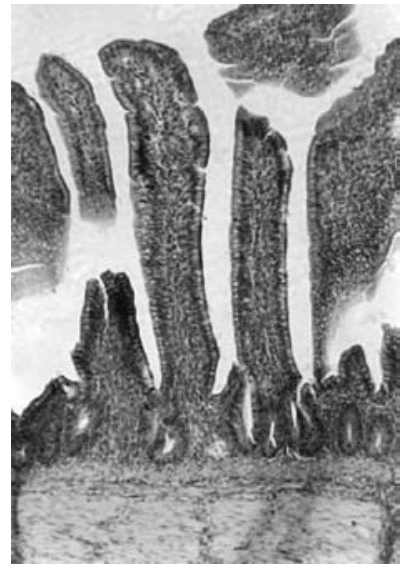

c. DFM

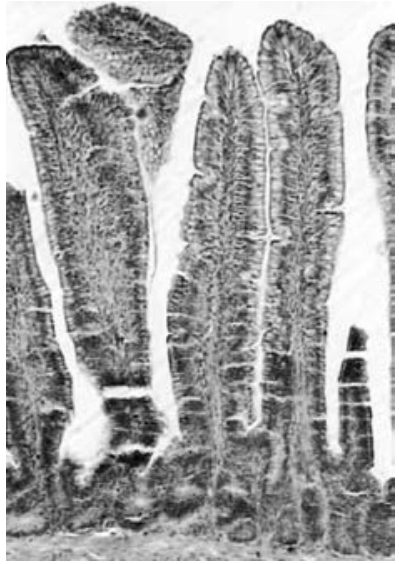

d. MOS

Figure 2. Histological figure of broiler ileum, (obj. 1:100, HE) for different treatment groups.

Figura histológica de ileon de broiler, (obj. 1:100, HE) para los diversos grupos en tratamiento.

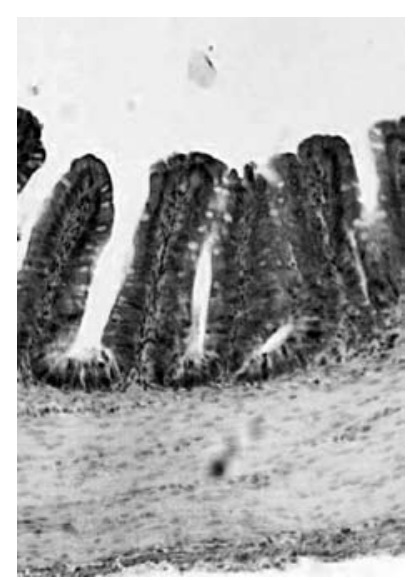

a. Control

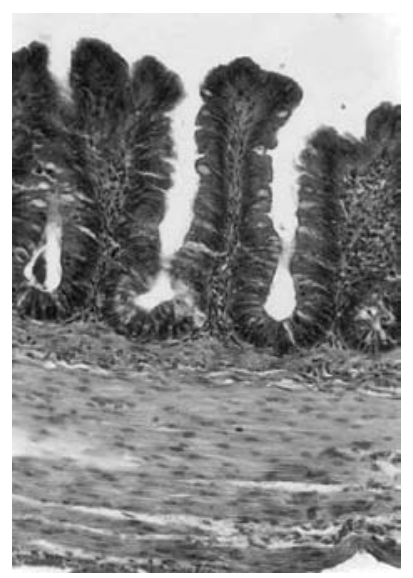

b. AGP

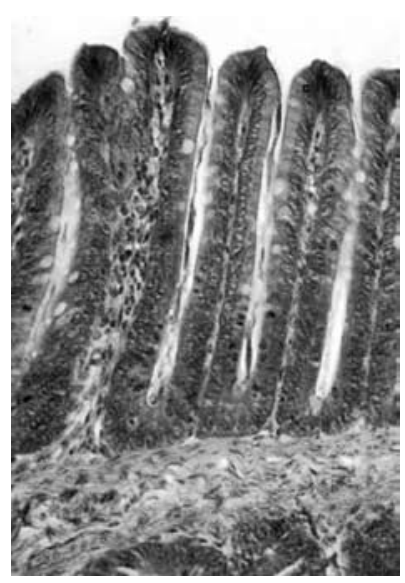

c. DFM

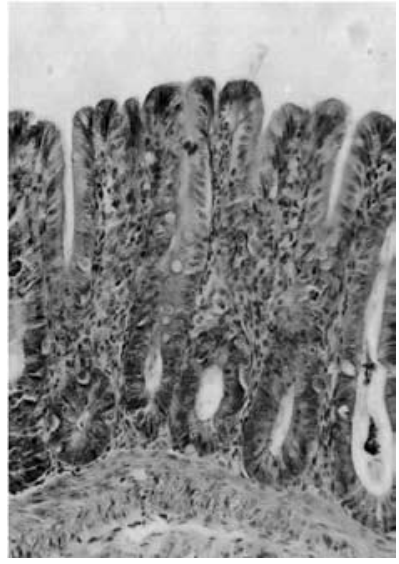

d. MOS

Figure 3. Histological figure of broiler caecum, (obj. 1:100, HE) for different treatment groups.

Figura histológica de intestino ciego de broiler, (obj. 1:100, HE) para los diversos grupos en tratamiento.

defined by Shane (2001). Enterocytes undergo a continual cycle of proliferation in the intestinal crypt, cell maturation and migration up the villa with desquamation at the tip of the villa. The depth of the crypts is correlated to cell replacement rate (Savage et al 1997). Accelerated replacement of enterocytes requires energy and proteins, which can deprive growth and the development of other tissues and organ systems. Thus, the decreased crypt height will be correlated to a significant increase in growth rate as occurred in the present study.

Adding DFM to broiler feed provides more stable resident microflora, which consequently provides better conditions for longer enterocyte life. Longer villa increases the absorptive surface of intestines, while smaller crypts indicate lower tissue turnover as well as lower demand for tissue development.

The evaluations performed have confirmed that antibiotics applied as growth promoters gave positive effects on average weight gain (5\% higher, on average) and on feed to gain ratio (approximate decrease of 6\%) in growing animals as reported by Gadd (1997). It has also been confirmed that feed supplements with probiotic and prebiotic effects both act as efficient growth promoters in domestic fowl, i.e. increasing daily gain for $8-10 \%$ with decreased feed gain ratio for $10-15 \%$, as described by Petersen (1998) and Owings et al (1990). On the basis of data obtained it was concluded that alternative growth promoters enhance growth by stimulation of physiological 
potentials and mechanisms in animals together with avoiding antibiotics in feeds as described by Ferket et al (2002) and Newman (2002). Probiotic and prebiotic supplements accomplish similar effects on animals as antibiotics, while undesired effects like tissue residua, withdrawal period, development of resistance in microorganisms, allergies, genotoxic effects, etc. are avoided as reported by Veld (1997) and Hooge (2003).

Antibiotics induce enlargement of villous length and width along with a decrease of depth of intestinal crypts, which can be correlated with a decrease of total microbial population and a shift to more beneficial composition of intestinal microflora.

These effects, especially the observed increase in duodenal villous length and decreased depth of the crypts are potentiated when probiotics are used. Dunham et al (1993) presented similar conclusions in domestic fowl fed a diet supplemented with L. Reuteri which had longer villa and lower crypts in ileum compared to the controls.

The most evident positive effects on digestion were achieved in intestines of broilers fed with feed supplemented with MOS. Olygosacharides can act negatively on digestion of energetic components as described by Coon et al (1990) and Leske et al (1993), as well as on the fact that volatile fatty acids stimulate peristalsis, therefore diminishing the period of food passage and possible time of absorption as reported by Hellendroon (1979). On the other hand, a compensatory mechanism reflected on the increase of villa length in the ileum has been reported by Choi et al (1994). Spring (1996) confirmed that mannan-olygocacharides in feed have a significant effect $(\mathrm{P}<0.05)$ on the length of the intestinal villa. They did not observe any significant difference in the width of the villa. The results obtained by Bradley et al (1994) and Shane (2001), who revealed that along with the increase of the length of intestinal villa a decrease of the crypt depth is observed, agree with this finding. The results of Savage et al (1997) have also confirmed that the depth of the crypts is decreased in the intestine of the broilers treated with MOS.

The described changes in intestinal morphology can explain the observed beneficial effects on productivity, as reported by Loodi et al (2004). The enlargement of the length and width of the intestinal villa increases the absorptive surface that is prominent when alternative growth stimulators are applied. At the same time the observed decrease of the depth of the crypts can indicate a decrease of enterocyte replacement and a decrease in cellular turnover.

It can be concluded that the use of probiotics and prebiotics as alternative growth promoters and controllers of growth entheropathogenic bacteria has nutritive, medical and economic advantages.

\section{SUMMARY}

A total of 240 Hybro broilers was divided into 4 groups. These groups were fed a complete corn/soybean based diet with and without addition of antibiotic growth promoters (AGP, Flavomycin ${ }^{\circledR} 15 \mathrm{ppm}$, Intervet), direct feed microbials (DFM, All-Lac ${ }^{\circledR} 1 \mathrm{~kg} / \mathrm{T}$, Alltech Inc. USA) and mannanoligosaccharide (MOS) (Bio-MOS ${ }^{\circledR} 2 \mathrm{~kg} / \mathrm{T}$, Alltech Inc. USA). Chickens were introduced into the experiment after hatching. At day 42 of trial, all broilers were conventionaly sacrificed in a slaughter plant and slaughter performances were measured. Samples of intestines with its content from 6 average broilers (randomly selected) from each group $(n=24)$ were taken for examination. At the end of the trial, body weight (BW) and body weight gain (BWG) of broilers fed the diet containing Bio-MOS $^{\circledR}$ (1915.23 and $\left.44.58 \mathrm{~g}\right)$, AGP (1869.40 and $\left.43.50 \mathrm{~g}\right)$ and DFM $(1855.50$ and $43.17 \mathrm{~g}$ ) were significantly higher than in birds of the control group (1815.67 and $41.96 \mathrm{~g}$ ). When compared with the control group ( $91.19 \mathrm{~g})$, ADFI (average daily feed intake) was also significantly reduced when Bio-MOS ${ }^{\circledR}(81.84 \mathrm{~g})$, DFM $(83.50 \mathrm{~g})$ or AGP $(86.16 \mathrm{~g})$ were supplemented which lead to a lower feed conversion ratio (FCR), 2.17 vs. $1.83,1.93$ and $1.98 \mathrm{~kg}$, respectively. A significantly lower $\mathrm{pH}$ of the intestinal content of intestines (duodenum, ileum, caecum) was observed in groups fed DFM $\left(6.16,6.46\right.$ and 6.72) and Bio-MOS ${ }^{\circledR}$ $(6.25,6.50$ and 6.78), compared with the control $(6.55,6.81$ and 7.21) and AGP $\left(6.61,6.87\right.$ and 7.14) group. The use of DFM and Bio-MOS ${ }^{\circledR}$ increased length and width of intestinal villa and decreased depth of crypts, while the number of goblet cells did not significantly differ among experimental groups. In conclusion, Bio-MOS ${ }^{\circledR}$ and DFM exhibited nutritional, pharmacological and economic advantages over antibiotic growth promoters.

\section{REFERENCES}

AVMA. 2001. Report of the AVMA Panel on Euthanasia. J Am Vet Med Assoc 218, 682 .

Bradly GL, TF Savage, KI Timm. 1994. The effect of supplementing diets with Saccharomyces cerevisiae var. Boulardii on male poult performance and ileal morphology. Poultry Sci 73, 1766-1770.

Choi KH, H Namkung, IK Paik. 1994. Effects of dietary fructooligosaccharides on the suppresion of intestinal colonization of Salmonella typhimurium in broiler chickens. Korean Journal of Animal Science 36, 271-284.

Coon CN, KL Leske, O Akavanichan, TK Cheng. 1990. Effect of olligosaccharide-free soybean meal on true metabolizable energy and fiber digestion in adult roosters and broilers. Zootechnica In, 9, 44-48.

Djolai M, L Somer, D Damjanov, L Hadnadjev, D Krnojelac. 1998. Volume density of intestinal glands in clinical remission of ulcerative colitis. Folia Anatomica 26, 56-57.

Dunham HJ, C Williams, FW Edens, IA Casas, WJ Dobrogosy. 1993. Lactobacillus reuteri immunomodulation of stressor-associated diseases in newly hatched chickens and turkeys. Poultry Sci 72 (Suppl 2), 103.

Ferket PR, CW Parks, JL Grimes. 2002. Mannan oligosaccharides versus antibiotics for turkeys. Nutritional biotechnology in the feed and food industries. Proceedings of Alltech's $18^{\text {th }}$ Annual Symposium, 43-64.

Fuller R. 1977. The importance of lactobacilli in maintaining normal microbial balance in the crop. Br Poultry Sci 18, 85-94.

Gadd J. 1997. Life without antibiotic digestive enhancers. In: Lyons TP (ed). Biotechnology in the feed industry. Proceedings Alltechs $13^{\text {th }}$ Annual Symposium, Nicholasville, Kentucky, USA, Pp 277-291.

Hellendroon EW. 1979. Benefical physiological activity of leguminous seeds. Qualitas plantarum 29, USA 227-244.

Hooge DM. 2003. Dietary mannan oligosaccharides improve broiler and turkey performance: meta-analysis of pen trials around the world. Nutritional biotechnology in the feed and food industries. Proceedings of Alltech's 19th Annual Symposium, 113-124.

Iji PA, Tivey DR. 1998. Natural and synthetic oligosaccharides in broiler chicken diets. Poultry Sci 2, 129-143.

Kumprecht I, P Zobac, V Siske, AE Sefton, P Spring. 1998. Effect of dietary mannan oligosaccharide level on performance and nutrient utilization of broilers. Poster. In: Lyons TP (ed). Biotechnology in 
the feed industry. Proceedings Alltechs $14^{\text {th }}$ Annual Symposium, Nicholasville, Kentucky, USA.

Leske KL, CJ Jevne, CN Coon. 1993. Effect of oligosaccharide additions on nitrogen corrected true metabolizable energy of soy protein concentrate. Poultry Sci 72, 664-668.

Loddi MM, VMB Moraes, LSO Nakaghi, FM Tuca, MI Hannas, J Ariki. 2004 Mannan oligosaccharide, organic acids on performance and intestinal morphometric characteristic of broilers chickens. Abstract of Alltechs $20^{\text {th }}$ Annual Symposium, Nicholasville, Kentucky, USA, Pp 45.

Marković R. 2005. The effect of different growth promoters in broiler nutrition on performance and health status. Master Thesis. Faculty of Veterinary Medicine, University of Belgrade, Belgrade, Serbia.

Miles RD, SM Bootwalla. 1991. Direct-fed microbials in animal production. In: Direct-fed microbials in animal production. A review. National Feed Ingredient Association, West Des Moines, Iowa, USA, Pp 117-132.

Newman K. 1999. Feeds with antibiotic growth promoters-The oligosaccharide alternative. Biotechnology Responds. Alltech's 1999 European, Middle Eastern and African Lecture Tour.

Newman M. 2002. Antibiotic resistance is a reality: novel techniques for overcoming antibiotic resistance when using new growth promoters. Nutritional biotechnology in the feed and food industries. Proceedings of Alltech's 18 ${ }^{\text {th }}$ Annual Symposium, Pp 97-106.

Owings WJ, DL Reynolds, RJ Hasiak, PR Ferket. 1990. Influence of dietary supplementation with Streptococcus faecium M-74 on broiler body weight, feed conversion, carcass characteristic and intestinal microbial colonization. Poultry Sci 69 1257-1264.

Parker RB. 1974. Probiotics, the other half of the antibiotics story. Animal Nutrition and Health 29, 4-8.

Pelicano ERL, PA De Souza, HBA De Souza, FR Leonel, NMBL Zeola, MM Boiago. 2004. Productive traits of broiler chickens fed diets containing different growth promoters. Rev Bres Cienc Avic 6, 177-182.

Petersen CB. 1998. Comparative effects of ZooLac, Bio-MOS and Bio-Pro on performance of broilers to 36 days. Poster. In: Lyons TP (ed). Biotechnology in the feed industry. Proc Alltechs $14^{\text {th }}$ Annual Symposium, Nicholasville, Kentucky, USA.

Roch C. 1998. Effect of Bio-MOS and Flavomycin on commercial broiler performance. Poster. In: Lyons TP (ed). Biotechnology in the Feed Industry. Proceedings Alltechs $14^{\text {th }}$ Annual Symposium, Nicholasville, Kentucky, USA.
Rolfe RD. 1991. Population dynamics of the intestinal tract. In: Blankenship LC (ed). Colonization control of human bacterial enteropathogens in poultry. Academic Press Inc., San Diego, USA, Pp 59-75.

Savage TF, EI Zakrzewska, JR Andersen. 1997. The effects of feeding mannan oligosaccharide supplemented diets to poults on performance and morphology of the small intestine. Poultry Sci 76, (Suppl. 1), 139.

Scheuer JP, TB Chalk. 1986. Clinical tests: Histology. Wolfe Medical Publ Ltd, Netherlands.

Shane MS. 2001. Mannan oligosaccharides in poultry nutrition: mechanism and benefits. Science and technology in the feed industry, 65-77.

Sharon N, H Lis. 1993. Carbohydrates in cell recognition. Scientific American 268, 82-89.

Snedecor GW, WG Cochran. 1956. Statistical methods applied to experiments in agriculture and biology. $5^{\text {th }} \mathrm{ed}$. Iowa State University Press, Ames, Iowa, USA.

Spring P. 1996. Effects of mannanoligosaccharide on different cecal parameters and on cecal concentrations of enteric pathogens in poultry. PhD thesis, Swiss Federal Institute of Technology, Zurich, Switzerland.

Spring, P, C Wenk, KA Dawson, KE Newman. 2000. The effects of dietary mannan oligosaccharides on cecal parameters and the concentrations of enteric bacteria in the caeca of Salmonella-challenged broiler chicks. Poultry Sci 79, 205-211.

Vanbelle M, E Teller, M Focant. 1990. Probiotics in animal nutrition: a review. Arch of Anim Nutr (Berlin) 40, 543-556.

Veld JHJ. 1997. Probiotics and the control of pathogens: what do we know? XI International Congress of the Veterinary Poultry Association, Abstracts, 111, Budapest, Hungary.

Waldroup P, CM Hillard, RJ Mitchell, DR Sloan. 1970. Response of broilers to moenomycin. Poultry Sci 49, 1264-1267.

Wiebel R. 1979. Practical methods bor biological morphometry. In: Stereological method. Academic Press, New York, USA, Pp 140156.

Xu ZR, CH Hu, MS Xia, XA Zhan, MQ Wang. 2003. Effects of dietary fructo oligosaccharide on digestive enzyme activities. Intestinal Microflora and morphology of male broilers. J Anim Sci 82, 10301036. 